$9-27-2000$

\title{
Jerusalem Policy Makes No Sense
}

Kenneth Lasson

University of Baltimore School of Law, klasson@ubalt.edu

Follow this and additional works at: http://scholarworks.law.ubalt.edu/all_fac

Part of the Immigration Law Commons, and the International Law Commons

\section{Recommended Citation}

Jerusalem Policy Makes No Sense,

This Editorial is brought to you for free and open access by the Faculty Scholarship at ScholarWorks@University of Baltimore School of Law. It has been accepted for inclusion in All Faculty Scholarship by an authorized administrator of ScholarWorks@University of Baltimore School of Law. For more information, please contact snolan@ubalt.edu. 


\section{Related Articles}

Three questions for the U.S. about Jerusalem

August 17, 2012

For peace, move the embassy

May 31, 1995

Israel's friends silent on Jerusalem

May 17, 1999

Dole embassy proposal stirs up Israel

May 13, 1995

Muslim clerics say embassy site theirs May 11, 1995

\section{Find More Stories About}

Israel

Jerusalem

Purpose

Embassy

\section{Jerusalem policy makes no sense}

September 27, 2000 | By Kenneth Lasson

REUVEN CHAIM WEISSMAN, our first grandson, is a baby without a country.

$\begin{array}{lll}\text { Recommend } & \sqrt{66} & \\ \text { Tweet } & \bullet \vdots & 0 \\ & \bullet \vdots & \mathbf{G}+1\end{array}$

Born recently in Jerusalem, this tiny apolitical person has just arrived in Baltimore from Israel with his proud parents, a journey that required him to have an American passport. All went smoothly at the U.S. consulate in East Jerusalem until I asked the woman processing the forms why there was no country listed after "Jerusalem" on the passport application.

"If your grandson had been born elsewhere in Israel," she said in an apparently well-rehearsed speech, "his passport would have named the state. But Jerusalem's status is and always has been in dispute, and that's why we don't list the country."

My outrage was muted by knowing that the absence of a national designation has no bearing on the passport's validity. Moreover, I understand the circumstances at the root of this bizarre State Department policy: the heavy-handed reluctance to offend Arab populations in the region.

Nevertheless, I wonder how my beloved country, my home of the free and the brave, founded on principles of liberty and justice for all and almost naively determined to treat everyone with fairness and wisdom, could allow itself this clear abdication of common sense.

In 1948, President Harry Truman, ignoring strong objections from the State Department, enabled the United States of America to become one of the first countries to recognize Israel. Jerusalem has always been Israel's capital. All U.S. embassies are situated in the host country's self-designated capital city, with the lone exception of Israel.

In 1995, Congress moved (by an almost unanimous vote) to correct this diplomatic aberration by requiring that our embassy be moved to Jerusalem. The land has already been purchased for the building.

But a clause was tacked on giving the president authority to postpone the move for temporary six-month periods "in the interest of U.S. security." President Clinton, who has said that he's "always wanted to move our embassy to West Jerusalem," has nevertheless consistently exercised this waiver, despite bipartisan opposition.

Last year, Sen. Joseph Lieberman joined nine other senators in a letter to Mr. Clinton urging him not to invoke the waiver: "Non-fulfillment of the law does no good to the U.S.-Israeli relationship or to prospects for Arab-Israel peace." George W. Bush, the Republican nominee for president, has vowed to start moving the embassy on his first day in office.

Even though Israel won all of Jerusalem in the 1967 war, even though no Israeli government nor popular referendum would ever allow another city to be designated its capital, even though the Arab-Palestinian peace process countenances no other place for that purpose -- in the view of the State Department, Jerusalem remains no man's land.

The U.S. government is not alone in this delusional semantic preoccupation. A few weeks ago, the Cable News Network decided that Jerusalem was no longer in Israel and summarily removed it from the list of cities noted in CNN's regional daily weather forecasts. Many geography books leave Israel off the world map, some still insisting that the speck of land surrounded by Arab countries be called "Palestine."

At best, this is little more than bureaucratic bone-headedness which flies in the face of recent past policy.

Bridling my cynicism at the consulate, I stopped short of asking the woman at the desk why the listing on the passport doesn't read "Occupied Jerusalem." But I haven't checked all of my impertinence at the consulate door.

"What if," I ask the clerk instead, "I were to insert the word Israel next to Jerusalem on my grandson's passport?"

"I'd strongly advise against it," she replied sternly. "The best that could happen is that you'd be cited for unlawfully tampering with an official government document. The worst would be that you're stopped at the border and thrown in jail."

The State Department can edit its passports out of its own misguided sense of political correctness. Madeleine Albright can camouflage her Jewish heritage to her heart's embarrassed content. I'm saying that my all-American grandson -who's named after my wife's late father (a GI wounded in World War II) and my late brother (who'd fight tooth and nail for what he thought was right and fair) -- I'm saying that Reuven Chaim Weissman was born in Jerusalem, Israel.

Kenneth Lasson is a law professor at the University of Baltimore.

\section{MORE:}

How to treat bone spurs

Grandson, 12, admits killing Shabazz But he says her death was not intended

'Blushing' ear is no cause for alarm

Senator's wife recounts terror, helplessness as victim of 
Minor's future arrives early Rookie didn't expect to make a start at third this season

Wrestler found shot dead family has lost five sons Latest tragedy apparently a suicide 